\title{
Piotr Ślęzak*
}

\section{AUDIOWIZUALNY UTWÓR NAUKOWY JAKO UTWÓR HYBRYDOWY?}

\begin{abstract}
Streszczenie
Niniejszy tekst stanowi próbę odpowiedzi na pytanie, czy audiowizualny utwór naukowy jest utworem hybrydowym. Byłoby to dzieło łączące w sobie cechy utworu naukowego i audiowizualnego. $\mathrm{Na}$ to pytanie autor udziela negatywnej odpowiedzi. Oceniane utwory są jedną z podkategorii utworu audiowizualnego. Za przyjęciem tej koncepcji przemawia to, że omawiany typ dzieła zawiera „warstwę” przekazującą treści naukowe, ale uzupełnioną przez niezwykle istotną „warstwę” stanowiącą emanację inwencji twórców audiowizualnych. Warstwa audiowizualna pozwala przybliżyć tematykę naukową i uczynić ją atrakcyjną dla odbiorców, którzy nie są specjalistami w danej dziedzinie. Zdaniem autora ,audiowizualny utwór naukowy” jest pojęciem zbiorczym, obejmującym przynajmniej trzy podkategorie: film dokumentalny, film oświatowy oraz film animowany. Obok tej kategorii istnieją ,czyste” dzieła naukowe, których składnikiem jest rejestracja audiowizualna.
\end{abstract}

Słowa kluczowe: audiowizualny utwór naukowy, utwór hybrydowy

\section{Wprowadzenie}

Utwór naukowy stanowi emanację i końcowy etap naukowego procesu poznawczego. Twórca referuje w nim wyniki swojego dążenia do wyjaśnienia

* dr hab. Piotr Ślęzak, prof. UŚ, Wydział Radia i Telewizji Uniwersytetu Śląskiego 
istniejącej rzeczywistości czy też praw rządzących tą rzeczywistością ${ }^{1}$. Wydaje się, że mamy tu do czynienia ,[...] z prawdami naukowymi sformułowanymi i wykrytymi przez autora $\mathrm{w}$ drodze spekulacji, doświadczenia i zestawienia z obiektywną rzeczywistością" ${ }^{2}$. Prawdy te mogą być wyrażone w taki sposób, że można je uznać za utwór - podlegają wówczas ochronie autorskoprawnej³ Bezdyskusyjne jest to, że w zdecydowanej większości przypadków autorzy wyrażają prawdy naukowe przy użyciu słów, symboli matematycznych i znaków graficznych. Fakt ten znajduje odzwierciedlenie normatywne w przepisie art. 1 ust. 2 pkt 1 pr. aut. W doktrynie z reguły za możliwe i dopuszczalne uznaje się wyrażenie prawd naukowych $\mathrm{w}$ inny sposób ${ }^{4}$. W związku $\mathrm{z}$ różnymi sposobami prezentacji wyników prac badawczych pojawia się pytanie, czy polski system prawny dopuszcza możliwość stosowania konstrukcji utworów hybrydowych oraz czy naukowy utwór audiowizualny jest przykładem utworu hybrydowego. Należy także rozstrzygnąć, jaki reżim prawny będzie stosowany do takich utworów. Przedmiotem dalszych rozważań będą jedynie takie utwory, które łączą cechy dzieła naukowego i dzieła audiowizualnego. Poza nurtem moich rozważań pozostaną dzieła naukowe, których składnikiem jest rejestracja audiowizualna (np. rejestracja kamerą eksperymentów w naukach technicznych czy w fizyce).

\section{Dopuszczalność stosowania konstrukcji utworu hybrydowego}

Kwestią wstępną, którą należy rozstrzygnąć w celu oceny utworów audiowizualnych o charakterze naukowym, jest ustalenie, czy polskie prawo autorskie pozwala posługiwać się konstrukcją utworu hybrydowego. Przez utwór hybrydowy należy rozumieć takie dzieło, które łączy w sobie elementy należące do utworów różnego rodzaju. Na tak postawione pytanie trzeba udzielić odpowie-

1 Por. A. Kopff, Dzieło sztuk plastycznych i jego twórca w świetle przepisów prawa autorskiego, „Zeszyty Naukowe Uniwersytetu Jagiellońskiego” 1961, z. 83, s. 10-11.

2 A. Szewc, Dzieła naukowe i ich status w prawie autorskim, „Państwo i Prawo” 1997, nr 10, s. 24.

3 Ustawa z dnia 4 lutego 1994 r. o prawie autorskim i prawach pokrewnych, tekst jedn. Dz.U. z 2016 r., poz. 666.

4 Zob. przykładowo: J. Barta, R. Markiewicz, w: Prawo autorskie i prawa pokrewne. Komentarz, red. J. Barta, R. Markiewicz, Warszawa 2011, s. 156; A. Nowicka, w: System prawa prywatnego, t. 13: Prawo autorskie, red. J. Barta, Warszawa 2013, s. 114-115; D. Sokołowska, Pojęcie i postacie utworu naukowego $w$ świetle prawa autorskiego, ,Ruch Prawniczy Ekonomiczny i Socjologiczny" 2015 , z. 2, s. 84-88 i podana tam literatura. 
dzi pozytywnej. Na gruncie polskiego prawa autorskiego wolno posługiwać się konstrukcją utworu hybrydowego. Ustawodawca polski, określając istotę dzieła jako przedmiotu ochrony prawnej, posługuje się syntetyczną definicją utworu (art. 1 ust. 1 pr. aut.). Przyjęcie takiego rozwiązania powoduje, że utworem w rozumieniu prawa autorskiego jest każdy wytwór niematerialny, który łącznie spełnia trzy przesłanki. Po pierwsze, stanowi wynik działalności umysłowej człowieka (twórcy); po drugie, przejawia się w nim twórczość (inaczej mówiąc, działalność twórcza o indywidualnym charakterze); po trzecie wreszcie, został ustalony w jakiejkolwiek postaci. Syntetyczną definicję ustawodawca uzupełnił, wyliczając „podstawowe” kategorie utworów (art. 1 ust. 2 pr. aut.)5. Wyliczenie to ma charakter jedynie przykładowy, co oznacza, że obok wymienionych przez ustawodawcę kategorii dzieł istnieją także inne rodzaje utworów. Nie ma powodu, aby odmówić statusu utworu wytworowi, który łączy w sobie cechy kilku tradycyjnych typów utworów. Naturalnie w tym przypadku spełnione muszą być przesłanki wymienione art. 1 ust. 1 pr. aut.

Skupmy się teraz na próbie odpowiedzi na pytanie, czy naukowy utwór audiowizualny jest utworem hybrydowym. Pozytywna czy negatywna odpowiedź na postawione pytanie ma wpływ na określenie reżimu prawnego omawianej kategorii utworów; a mianowicie pozwala rozstrzygnąć, czy i w jakim zakresie należy do nich stosować przepisy dotyczące utworu naukowego, czy może przepisy dotyczące utworu audiowizualnego.

\section{Istota utworu audiowizualnego o charakterze naukowym}

Uznaliśmy, że ochronie autorskoprawnej podlega utwór, który możemy dookreślić za pomocą przymiotników „naukowy” i „audiowizualny”. Tak więc wstępnie możemy założyć, że jest to utwór hybrydowy. Należy zastanowić się, co wskazane określenia oznaczają w kontekście potrzeb niniejszego opracowania.

W języku potocznym ,naukowy” to taki, który ma związek z nauką w ogóle lub z jakąś jej dziedziną. Natomiast termin „nauka” odnosi się m.in. do studiów nad rzeczami czy zjawiskami oraz do wiedzy, która z tych studiów wynika ${ }^{6}$. Natomiast w doktrynie prawa autorskiego jedną z najtrafniejszych i bodaj najczęściej cytowanych definicji utworu naukowego sformułował H. Haberstumpf.

5 P. Ślęzak, Prawo autorskie. Podręcznik dla studentów szkót filmowych, Katowice 2015, s. 38.

6 Zob. Inny stownik języka polskiego. A...Ó, red. M. Bańko, Warszawa 2000, s. 962 [hasła „nauka” i ,naukowy”]. 
Zdaniem tego autora dziełem naukowym jest utwór, którego podstawowa funkcja komunikacyjna ma cel informacyjny; utwór taki nie jest nakierowany na siebie, lecz na przedstawiony w nim, obiektywnie istniejący stan rzeczy? ${ }^{7}$.

Punktem wyjścia rozważań nad utworem naukowym, jako przedmiotem ochrony autorskoprawnej, jest pojęcie „nauki”. Wydaje się, że naukę należy traktować jako jeden z segmentów wiedzy ludzkiej. Jest to segment najlepszy pod względem poznawczym, ponieważ adekwatnie opisuje rzeczywistość ${ }^{8}$. Składnikami, które powodują, że dzieło naukowe ma walor poznawczy, są język i metoda ${ }^{9}$. Uważam, iż ,język" dzieła naukowego służy do przekazania treści naukowych. Można przyjąć, że „Treść dzieła naukowego [...] polega na maksymalnie wiernym i jednoznacznym opisie rzeczywistości lub ujawnieniu jej prawidłowości"10. Treść ta może być wyrażona zarówno w postaci systemu znaków służących do porozumiewania się w mowie i w piśmie ${ }^{11}$ (w tradycyjnym dziele naukowym), jak i w postaci języka filmu. W znaczeniu szerokim termin ten oznacza audiowizualny system znaków, za pomocą którego może być wyrażony dowolny komunikat kinematograficzny. W tym kontekście ,język filmu” obejmuje film, telewizję, jak i inne sposoby przekazu złożonego z ruchomych obrazów. Natomiast w znaczeniu wąskim omawiany termin oznacza specyficzny system językowy, na który składa się słownik, tzn. zespół wizualnych i audialnych znaków występujących w procesie komunikacji filmowej, oraz gramatyka, czyli reguły łączenia jednostek słownika w tekst ${ }^{12}$. Warto zwrócić uwagę na to, że treść dzieła naukowego zawiera także elementy pozatekstowe. A. Szewc zalicza do nich: 1) temat, czyli celowo wybrany fragment rzeczywistości, którego dzieło dotyczy; 2) pomysł badawczy, tzn. idea, hipoteza, sugestia istnienia określonych prawidłowości, ogólna koncepcja wyjaśnienia problemu, oryginalne pytanie badawcze; 3) fakty naukowe, tzn. ustalenia dotyczące pojedynczych zdarzeń albo właściwości o charakterze przyrodniczym lub społecznym; 4) rozumowanie, które obejmuje: wnioskowanie, dowodzenie, wyjaśnianie, interpretację i wery-

7 H. Haberstumpf, Zur Individualität wissenschaftlicher Sprachwerke, Freiburg 1982, s. 22-26.

8 Por. tekst zawarty na stronie internetowej https://pl.wikipedia.org/wiki/Nauka (dostęp 21.10.2016).

9 Tak M. Heller, Filozofia nauki, Kraków 2016, s. 11.

10 R. Markiewicz, Ochrona prac naukowych, ,Zeszyty Naukowe Uniwersytetu Jagiellońskiego. Prace z Wynalazczości i Ochrony Własności Intelektualnej” 1990, z. 55, s. 17.

11 Jest to słownikowe rozumienie terminu ,język”. Zob. Inny stownik k.., s. 576 [hasło ,język"].

12 M. Hendrykowski, Stownik terminów filmowych, Poznań 1994, s. 130 [hasło ,język filmu”]. 
fikację; 5) dobór faktów i rozumowań; 6) syntezę naukową, czyli uogólniające ujęcie cech charakterystycznych pewnego zbioru przedmiotów; 7) systematyzację, tzn. uporządkowanie obiektów (przedmiotów, zjawisk i procesów) lub pojęć o ogólnych cechach wspólnych według określonego systemu klasyfikacji13.

Działania, które możemy zakwalifikować jako naukowe, powinny być poprawne metodologicznie. Oznacza to, że formułowanie twierdzeń i teorii naukowych odbywa się z zastosowaniem określonych metod. Można mówić o metodologii ogólnej stosowanej we wszystkich naukach (np. we wszystkich dziedzinach nauki stosowane są prawa logiki formalnej) oraz o metodologiach poszczególnych dyscyplin naukowych ${ }^{14}$.

Treści naukowe mogą być przekazane potencjalnemu odbiorcy jako materiał audiowizualny w ten sposób, że można je zakwalifikować jako utwór.

Charakter audiowizualny mają takie materiały, które składają się z: 1) obrazów; 2) wyrażonych jako sekwencja; 3) sprawiających w czasie odtwarzania wrażenie ruchu; 4) udźwiękowionych lub nieudźwiękowionych; 5) utrwalonych na dowolnym nośniku ${ }^{15}$. Obraz widoczny na zdjęciu, ekranie, trójwymiarowym modelu itp. to osoby, rzeczy, które na nim widzimy; jest to także fragment akcji, który rozgrywa się $\mathrm{w}$ tej samej scenerii ${ }^{16}$. Tak więc $\mathrm{w}$ sensie potocznym jest to wizualna strona utworu filmowego - w przeciwieństwie do jego strony dźwiękowej. Inaczej mówiąc, są to utwory stworzone w konwencji filmowej ${ }^{17}$, a więc oparte na wcześniej powstałym scenariuszu, mające fabułę wyrażoną środkami wizualnymi i dźwiękowymi, w sposób wywołujący wrażenie ruchu ${ }^{18}$. Natomiast w ujęciu filmoznawczym jest to zapis kinematograficzny wyglądów rzeczywistości, ich ruchomy obraz utrwalony na nośniku oraz nośnik znaczenia filmowego ${ }^{19}$. Wskazane przesłanki uznania konkretnego materiału za audiowizualny zostały sformułowane na podstawie przepisu art. 4 ust. 1 ustawy z dnia 30 czerwca 2005 r. o kinematografii ${ }^{20}$, zawierającego definicję legalną filmu. Wspomniana definicja została sformułowana na potrzeby u.k.,

13 A. Szewc, Dzieła naukowe..., s. 24-25.

14 Zob. informacje na stronie internetowej https://pl.wikipedia.org/wiki/Metodologia_nauk (dostęp 25.10.2016).

15 Por. P. Ślęzak, Umowy w zakresie współczesnych sztuk wizualnych, Warszawa 2012, s. 124.

16 Zob. Inny słownik..., s. 1071 [hasło „obraz”].

17 Tak M. Paschke, Medienrecht, Heidelberg-London-New York 2009, s. 26, 67.

18 Por. M. Czajka, Ochrona praw twórców i producentów, Warszawa 2010, s. 70.

19 Tak M. Hendrykowski, Stownik terminów filmowych, s. 202-203 [hasło „obraz”].

20 Tekst jedn. Dz. U. z 2015 r., poz. 1403, z późn. zm. 
a więc aktu o charakterze administracyjnoprawnym, jednakże może zostać pomocniczo zastosowana do scharakteryzowania istoty utworu audiowizualnego na gruncie pr. aut. ${ }^{21}$ Wymienione przesłanki wymagają omówienia.

Po pierwsze, zauważmy, że ustawodawca, używając wyrażenia ,seria następujących po sobie obrazów", wskazuje, iż materiał audiowizualny nie jest prostym zbiorem obrazów, lecz ich sekwencją. Sekwencja oznacza jednostkę kompozycji utworu filmowego, stanowiącą samodzielny pod względem dramaturgicznym element konstrukcji filmu, złożony z szeregu ujęć i scen ${ }^{22}$. Wydaje się, że już samo słowo „seria” wyraźnie wskazuje na wymóg istnienia koherencji (spójności) obrazów. Ustawodawca nie przesądza „natężenia” tej spójności. Wydaje się, że dla jej spełnienia wystarczy istnienie relacji, które wykluczają indyferentność obrazów względem siebie ${ }^{23}$. Tak więc nie każdy materiał audiowizualny musi wyrażać akcję (treść), ale między kilkoma obrazami wytwarza się dostrzegalna więź, powodująca, iż stają się one jednością. Należy także wskazać, że „seria obrazów” musi posiadać wewnętrzną cechę (charakterystyczną dla wszystkich utworów z wyjątkiem multimediów ${ }^{24}$ ) polegającą na tym, że percepcja poszczególnych obrazów następuje w określonej (narzuconej inwencją twórców) kolejności²5.

Po drugie, scharakteryzowana "seria następujących po sobie obrazów" powinna w czasie odtwarzania „wywoływać wrażenie ruchu”. Należy przyjąć za SA w Paryżu ${ }^{26}$, że „Ruch i obraz są [...] esencją sztuki kinematograficznej”. Ustanawiając wymóg ,ruchomości” obrazu, ustawodawca, jak się wydaje, zakłada, że ma ona charakteryzować konkretną sekwencję samą w sobie, a nie wynikać z przejścia między jedną sekwencją a drugąą. Zauważmy, że w aktualnym stanie prawnym pr. aut. nie zawiera expressis verbis wymogu wywoływania wrażenia

21 Tak P. Ślęzak, Umowy w zakresie wspótczesnych sztuk wizualnych, s. 124; inaczej M. Ożóg, Podstawowe pojęcia ustawy z 30.06.2005 r. o kinematografii, „Zeszyty Naukowe Uniwersytetu Jagiellońskiego. Prace z Prawa Własności Intelektualnej” 2009, z. 104, s. 124-126.

22 Por. M. Hendrykowski, Stownik terminów filmowych, s. 269 [hasło ,sekwencja”].

23 Tak A. Wojciechowska, Autorskie prawa osobiste twórców dzieła audiowizualnego, „Zeszyty Naukowe Uniwersytetu Jagiellońskiego. Prace z Wynalazczości i Ochrony Własności Intelektualnej" 1999, z. 72, s. 55.

24 Dla multimediów charakterystyczna jest tzw. niesekwencyjna kolejność percepcji. Zob. P. Ślęzak, Dzieło multimedialne w świetle polskiego prawa autorskiego, ,Zeszyty Naukowe Uniwersytetu Jagiellońskiego. Prace z Wynalazczości i Ochrony Własności Intelektualnej” 2003, z. 83, s. 10-11.

25 Por. A. Wojciechowska, Autorskie prawa osobiste..., s. 56.

26 Wyrok z 31 maja 1964 r., JCP 1964, éd. G, II, 13932.

27 Zob. J.-Ch. Galloux, Oeuvre audiovisuelle, w: JurisClasseur, Propriété littéraire et artistique, z. 1140, Paris 2002, s. 14. 
ruchu przez utwór audiowizualny ${ }^{28}$. Wydaje się, że ustawodawca, używając sformułowania „utwór audiowizualny”, zwraca uwagę przede wszystkim na wizualną stronę takich utworów i abstrahuje od faktu, czy wywołują one w czasie odtwarzania wrażenie ruchu. Oczywiście większość materiałów audiowizualnych to materiały „ożywione”; jednakże nic nie wskazuje, by wolą ustawodawcy było wyłączenie spod kategorii utworu audiowizualnego wytworów, które w czasie odtwarzania wywołują u odbiorcy wrażenie powoli zmieniającego się, niemal statycznego obiektu. Tak więc można dojść do wniosku, że nie każdy utwór audiowizualny musi wywoływać wrażenie ruchu. Zawartość intelektualna utworu ma się wyrażać za pomocą środków wizualnych. Środki te mogą wywoływać w czasie projekcji wrażenie ruchu (w sposób realistyczny lub sztuczny ${ }^{29}$ ) albo mogą być formą statyczną, o ile jednak można jej przypisać walor serii obrazów. W tej sytuacji prezentowane obrazy jedynie pozornie stanowią kilka następujących po sobie fotografii. Czynnikiem, który decyduje o uznaniu ich za jednolity materiał audiowizualny, jest fakt, iż tworzą one serię, czyli istnieje jakiś racjonalny powód, by oglądać te obrazy w określonej kolejności ${ }^{30}$. Należy przyjąć, że sfera wizualna jest konstytutywnym elementem utworów audiowizualnych ${ }^{31}$.

Po trzecie, materiały audiowizualne mogą, choć nie muszą, zawierać warstwę dźwiękową. Obecność dźwięku nie jest konstytutywnym elementem materiałów audiowizualnych. Zauważmy, że wykładnia językowa przepisu art. 1 ust. 2 pkt 9 pr. aut. prowadzi do wniosku, że pod pojęciem „utwór audiowizualny” należy rozumieć utwór, który stanowi połączenie warstwy dźwiękowej i wizualnej. Jednakże wykładnia celowościowa pozwala stwierdzić, że warstwą wiodącą jest warstwa wizualna, natomiast dźwięk jest elementem fakultatywnym ${ }^{32}$.

Po czwarte wreszcie, udźwiękowiona lub nieudźwiękowiona seria obrazów ma być zapisana na nośniku materialnym dowolnego rodzaju. Uniezależnienie utworów audiowizualnych od rodzaju nośnika jest istotnym osiągnięciem

28 Wydaje się, że o ustawowym wymogu ruchu na gruncie prawa polskiego można było mówić w czasie obowiązywania ustaw z 1926 i 1952 r., kiedy ustawodawca posługiwał się kategorią utworu kinematograficznego. Jak wskazuje greckie pochodzenie wyrazu „kinematograficzny” (kinéma, kinématos - ruch + gráphõ - piszę), utwór tego rodzaju musiał wywoływać w czasie odtwarzania wrażenie ruchu.

29 Płynność ruchu uzyskuje się przy rzutowaniu na ekran przynajmniej 16 klatek. Jednakże w tej sytuacji ruch jest nienaturalny (szybszy od rzeczywistego). Natomiast rzutowanie 24 klatek daje efekt naturalnego ruchu.

30 P. Ślęzak, Umowy w zakresie wspótczesnych sztuk wizualnych, s. 126-127.

31 Zob. D. Flisak, Utwór multimedialny w prawie autorskim, Warszawa 2008, s. 91.

32 Ibidem. 
współczesnego prawa autorskiego. W aktualnym stanie prawnym pozbawiona znaczenia jest technika, w jakiej materiał został pierwotnie zarejestrowany, czy późniejsze zmiany techniki zapisu w czasie rozpowszechniania materiału. Pozwala to na objęcie pojęciem utworu audiowizualnego materiałów zarejestrowanych na taśmie przejrzystej, magnetycznej i zapisu cyfrowego ${ }^{33}$.

Jak wiadomo, jedną z przesłanek zaliczenia konkretnego wytworu umysłu człowieka do kategorii utworów w rozumieniu prawa autorskiego jest jego twórczy charakter. Zgodnie z przepisem art. 1 ust. 1 pr. aut. utwór ma być przejawem działalności twórczej o indywidualnym charakterze, Twórczość ma dwie cechy. Po pierwsze, jest przejawem działalności twórczej (jest to tzw. oryginalność); po drugie, jest to działalność mająca indywidualny charakter (tzw. indywidualność). Wypada zastanowić się, w czym przejawia się twórczość w utworze naukowym i w utworze audiowizualnym.

Indywidualność należy uznać za swego rodzaju „,pomost” łączący osobę twórcy $\mathrm{z}$ utworem i uzasadniający przyznanie mu osobistych praw autorskich. W przypadku utworów audiowizualnych dzieło jest indywidualne w tym sensie, że pokazuje, w jaki sposób jego twórcy postrzegają świat. Utwór zasługuje na ochronę, ponieważ jest „duchowym dzieckiem” swego twórcy ${ }^{34} \mathrm{~W}$ tym sensie, że twórca pozostawia na nim „piętno” swej osobowości, tworząc w ten sposób swój własny niepowtarzalny styl ${ }^{35}$. Natomiast w utworze naukowym, jak się wydaje, indywidualność jest równoznaczna ze sposobem prowadzenia wywodu, doborem argumentów i przykładów ${ }^{36}$.

Należy przyjąć, że ,oryginalne jest to, co bierze początek w umyśle twórcy"37. Dzieło jest chronione jako utwór, jeśli różni się od tego, co już jest znane (nowość), oraz od tego, co z niego bezpośrednio wynika (oryginalność). W tym kontekście można powiedzieć, że oryginalność jest wyższym stopniem nowości ${ }^{38}$. Sama rejestracja materiału audiowizualnego nie przesądza o jego oryginalności. Oryginalność jest nowatorstwem w zakresie formy utworu. Twórcy uzewnętrzniają stan swoich przeżyć psychicznych, nadają im nową, tzn. wzbogacającą istniejący stan rzeczy, formę ${ }^{39}$. Natomiast w utworze naukowym o oryginalności

33 P. Ślęzak, Umowy w zakresie wspótczesnych sztuk wizualnych, s. 128.

34 Tak F. Dessemontet, Le droitd 'auteur, Lausanne 1999, s. 116.

35 Zob. P. Ślęzak, Utwory współczesnych sztuk wizualnych, s. 107.

36 Na kwestie te zwraca uwagę R. Markiewicz w: Ochrona prac naukowych, s. 20.

37 M. Poźniak-Niedzielska, A. Niewęgłowski, w: System..., t. 13, s. 14.

38 Tak I. Cherpillod, L'objetdudroitd auteur, Lausanne 1985, s. 133.

39 Por. P. Ślęzak, Utwory współczesnych sztuk wizualnych, s. 128. 
przesądzają dowody, czyli zestawienie tez z obiektywną rzeczywistością, istniejącą poza twórcą i niezależnie od jego woli.

Wydaje się, że ,audiowizualny utwór naukowy” jest pojęciem zbiorczym, obejmującym trzy podkategorie: film dokumentalny, oświatowy oraz animowany. Kryterium wyróżnienia wspomnianych podkategorii jest sposób audiowizualnej prezentacji treści naukowych. W moim odczuciu wymienione podkategorie mają cechę wspólną, a mianowicie zawierają ,warstwę" przekazującą treści naukowe, uzupełnioną przez „warstwę" stanowiącą emanację inwencji twórców audiowizualnych. Zastosowanie warstwy audiowizualnej może wynikać z konieczności albo z chęci uatrakcyjnienia przekazywanych treści albo obu powodów jednocześnie. Konieczność pojawia się wówczas, gdy materiał audiowizualny wydaje się jedynym sposobem przekazania wyników pracy naukowej w określonej dziedzinie wiedzy, np. ze względu na wyjątkowość eksperymentu, znaczne koszty jego powtórzenia, utrudniony dostęp do określonych miejsc czy specyficzne warunki pracy kamery ${ }^{40}$. Uatrakcyjnienie przekazywanych treści ma znaczenie przede wszystkim dla odbiorcy, który nie jest specjalistą z określonej dziedziny naukowej, a chciałby pogłębić swoją wiedzę. Oba powody pojawiają się w utworach stanowiących rekonstrukcję wydarzeń historycznych, które nie zostały wcześniej utrwalone kamerą. Biorąc to pod uwagę, za celowe i uzasadnione uważam stosowanie dla omawianej kategorii utworów nazwy „utwory audiowizualne o charakterze naukowym". Wynika to stąd, że mamy tu do czynienia z materiałem audiowizualnym zawierającym treści naukowe. Co więcej, należy uznać, że warstwą podstawową i wyjściową jest warstwa audiowizualna, tyle że służy ona przekazywaniu treści o charakterze naukowym.

Film dokumentalny należy, obok filmu fabularnego, do podstawowych rodzajów filmu ${ }^{41}$. Można przyjąć, że „Wyznaczenie rodzajów filmowych przebiega w oparciu o takie kryteria, jak treść filmu, technika jego realizacji, wybór i uszeregowanie rejestrowanego materiału, czy też planowane przez twórców wrażenie, jakie utwór wywrzeć ma na odbiorcy”42. Film dokumentalny to, inaczej mówiąc, film faktu, w przeciwieństwie do filmu fabularnego, który jest fikcją. Przez film dokumentalny należy rozumieć „,wszelkie metody dokumentowania na taśmie filmowej rozmaitych aspektów rzeczywistości interpretowanych bądź jako faktycznie sfilmo-

40 Zob. D. Wierski, Rodzaje i gatunki filmowe, s. 1, https://pl.wikipedia.org/wiki/Film_edukacyjny (dostęp 3.11.2016).

41 Innymi, poza wymienionymi, rodzajami filmu są filmy eksperymentalne, oświatowe oraz animowane. Por. informacje zawarte na stronie internetowej http:/www.edukacjafilmowa.pl/materialy-edukacyjne/inne-opracowania/item/2142-rodzaje-i-gatunki-filmowe (dostęp 8.11.2016).

42 Ibidem. 
wane, bądź też jako jej wiarygodna i usprawiedliwiona rekonstrukcja" ${ }^{\text {"3 }}$. Wydaje się, że w treści naukowe mogą być przekazywane w obrębie „klasycznego” filmu dokumentalnego albo jako film paradokumentalny. Klasyczny film dokumentalny przedstawia wybrane fakty, które miały miejsce w rzeczywistości (np. prowadzenie badań naukowych czy eksperymentów w określonej dyscyplinie naukowej), ukazuje autentyczne postacie (np. zespół naukowców przy pracy). Jednocześnie jednak jest subiektywną wizją autorów, w tym sensie, że selekcjonują oni zarejestrowany materiał, decydują o jego układzie, ustawieniu kamery. Nierzadko film zawiera także elementy inscenizowane ${ }^{44}$. Filmy takie prezentują fakty naukowe i dane zebrane przez naukowców oraz wypływające z nich wstępne wnioski ${ }^{45}$. Filmy dotyczące wydarzeń historii współczesnej niejednokrotnie zawierają materiały archiwalne czy też stanowią kompilację takich materiałów uzupełnionych komentarzem ${ }^{46}$. Z kolei filmy paradokumentalne są utworami częściowo ${ }^{47}$ albo całkowicie ${ }^{48}$ inscenizowanymi, wykorzystującymi z myślą o większej wiarygodności ekranowego świata poetykę filmu dokumentalnego. Twórcy takiego filmu dążą do maksymalnego uprawdopodobnienia i autentyzacji pokazywanej rzeczywistości ${ }^{49}$. Współczesne platformy cyfrowe zawierają kanały specjalizujące się w filmie popularnonaukowym. Przykładem jest kanał Planète+, prezentujący filmy popularnonaukowe $\mathrm{z}$ takich dziedzin wiedzy, jak historia ${ }^{50}$, nauka i technika ${ }^{51}$, dzika natura ${ }^{52}{\text {, } \text { biografie }^{53} \text {, odważni }}^{54}$.

43 Definicja sformułowana przez World Union of Documentary w 1948 r., cyt. za: M. Hendrykowski, Słownik terminów filmowych, s. 62 [hasło „dokumentalny film”].

44 Tak D. Wierski, Rodzaje i gatunki filmowe, s. 1-2.

45 Przykładem są serie dokumentalne: „Starożytni kosmici” i „Czysta nauka”.

46 Przykładem są serie dokumentalne: „Apokalipsa: I wojna światowa”, „Apokalipsa: II woja światowa".

47 Przykładem jest 5-częściowy cykl filmowy „Tajemnice początków Polski”.

48 Przykładem jest serial dokumentalny BBC „Egipt”, przedstawiający dzieje odkrycia grobowca Tutanhamona przez Howarda Cartera.

49 Zob. M. Hendrykowski, Stownik terminów filmowych, s. 215 [hasła „paradokumentalizm” i ,paradokumentalny film”].

50 Np. cykl BBC „Opowieści z wielkiej wojny”, prezentujący I wojnę światową z perspektywy zwykłego człowieka.

51 Np. cykl BBC „Nauka w obszarach absurdu”, prezentujący w humorystyczny sposób kontrowersyjne eksperymenty naukowe.

52 Np. francuski cykl „Ushuaia, czyli wszystko w naturze”, prezentujący biologiczny system Ziemi.

53 Np. biografie Franka Sinatry czy Johnny'ego Casha.

54 Np. film „W pogoni za słońcem” - opowieść o polskich studentach biorących w $2015 \mathrm{r}$. udział w międzynarodowym wyścigu Bridgestone World Solar Challenge w Australii. 
Film oświatowy (dydaktyczny) jest utworem o charakterze dokumentalnym albo paradokumentalnym, zaznajamiającym odbiorcę z określoną dziedziną wiedzy, popularyzujący osiągnięcia nauki (tzw. film popularnonaukowy), wykorzystywany w procesie nauczania jako element atrakcyjnego kształcenia. Można przyjąć, że filmy omawianego rodzaju charakteryzują następujące cechy: 1) są jednym z gatunków filmu naukowego, 2) są dostosowanego do określonego programu nauczania, 3) są zbudowane według zasad dydaktyki, 4) stanowią część określonej metody nauczania ${ }^{55}$. Wyróżnikiem tego rodzaju dzieł jest dominanta funkcji poznawczej w połączeniu ze specyficzną dramaturgią przekazu zmierzającego do poglądowego ukazania danego zjawiska czy obszaru wiedzy ${ }^{56}$. Są one narzędziem pedagogicznym, za pomocą którego realizowane są określone cele kształcenia ${ }^{57}$. Celami tymi są: wiedza, umiejętności, rozwijanie zdolności poznawczych, rozwijanie zainteresowań oraz kształtowanie naukowego poglądu na świat ${ }^{58}$. Film animowany generowany komputerowo jest podgatunkiem grafiki komputerowej i animacji. Filmy takie są cyfrowymi odpowiednikami animacji nieruchomych obiektów trójwymiarowych (np. kukiełek) i animacji poklatkowej ilustracji płaskich ${ }^{59}$. Do celów popularyzujących osiągnięcia nauki wykorzystywane są filmy całkowicie generujące rzeczywistość wirtualną ${ }^{60}$ i częściowo generujące taką rzeczywistośśc ${ }^{61}$.

W moim odczuciu podstawową cechą naukowego utworu audiowizualnego jest fakt, że stanowi on przejaw działalności twórczej polegający na specyficznym połączeniu faktów naukowych i wyobrażeń twórców filmowych co do możliwych sposobów prezentacji tych faktów. Cecha ta przesądza, jak się wydaje, o tym, że omawiana kategoria utworów nie należy do dzieł hybrydowych, lecz jest podkategorią dzieł audiowizualnych. Zasygnalizowane zjawisko najlepiej zilustruje przykład. Wyobraźmy sobie film naukowy omawiający kwestię adaptacji dinozaurów do warunków środowiska, w którym

55 Tak W. Strykowski, Struktura filmu naukowo - dydaktycznego, Poznań 1973, s. 104.

56 Ibidem, s. 210 [hasło „oświatowy film”].

57 Tak W. Strykowski, Wstęp do teorii filmu dydaktycznego, Poznań 1977, s. 37.

58 Ibidem, s. 43-49.

59 Zob. informacje zawarte na stronie internetowej https://pl.wikipedia.org/wiki/Animacja_ komputerowa (dostęp 14.11.2016).

${ }^{60} \mathrm{~Np}$. symulatory lotu samolotem czy symulatory lotu kosmicznego, interaktywne doświadczenia w medycynie.

${ }^{61}$ Np. seriale BBC „Wędrówki z dinozaurami”, „Wędrówki z bestiami”. 
żyły. Z jednej strony film taki przedstawia fakty naukowe ustalone i głoszone przez paleontologów. Mam tu na myśli fakty, których ustalenie jest możliwe na podstawie wykopalisk, dotyczące wyglądu, sposobu poruszania się dinozaurów, ich sposobu zachowania się (np. sposobu odżywiania się czy zachowania w odniesieniu do młodych). Należy założyć, że od czasu narodzin współczesnej paleontologii, rozumianej jako historia życia na Ziemi, na przełomie XVIII i XIX w. naukowcy zgromadzili miliony danych, które pozwalają na rekonstrukcję życia dinozaurów. Jednakże rekonstrukcja ta jest jedynie częściowa, co pozostawia miejsce dla różnorodnych teorii wyjaśniających konkretne zjawiska oraz dla wyobraźni twórców filmowych. Warto zauważyć, że badaczom nie udało się do tej pory jednoznacznie ustalić, czy dinozaury były zwierzętami zmiennocieplnymi czy stałocieplnymi ${ }^{62}$. Wyobraźnia twórców filmowych jest uruchamiana w tych momentach, w których nie ma jednoznacznych faktów naukowych pozwalających zweryfikować czy sfalsyfikować konkretną teorię. Przykładowo można wskazać na fakt, iż przez dziesięciolecia wykopaliska dostarczały wyłącznie informacji o szkieletach, dopiero stosunkowo niedawno odnaleziono pozostałości tkanek miękkich ${ }^{63}$. Jednakże nawet dostępność fragmentów skóry nie przesądza o jej kolorze oraz o ewentualnym upierzeniu zwierzęcia czy też jego braku. Kwestie te „uzupełniają” twórcy filmu, kierując się sugestiami paleontologów.

Wydaje się, że w przypadku omawianej w niniejszym artykule kategorii utworów „nasycenie” konkretnego dzieła elementami stworzonymi przez twórców filmowych jest na tyle duże, że stanowi kolejny argument przemawiający za stosowaniem do nich nazwy „dzieła audiowizualne”, a nie „utwory naukowe”. Twórcy przedstawiają fakty i teorie naukowe, wykorzystując jako tworzywo artystyczne światło i dźwięk. Można przyjąć, że omawiane dzieło wykazuje powinowactwo z dziełem naukowym wyrażonym słowem, symbolami matematycznymi i znakami graficznymi. Inaczej mówiąc, „,kino jest widzialną i słyszalną literaturą" ${ }^{94}-\mathrm{w}$ omawianym przypadku literaturą naukową. Taki sposób postawienia

62 Por. informacje na stronach internetowych http://kopalniawiedzy.pl/dinozaurystalocieplnosc-zmiennocieplnosc-energetyka-metabolizm,8989, https://pl.wikipedia.org/wiki/ Zwierz\%C4\%99_sta\%C5\%82ocieplne; http://www.geekweek.pl/aktualnosci/23257/dinozaury-byly-stalocieplne (- dostęp 15.11.2016).

63 Przykładem jest Scypionyx nazwany Cyrusem, odkryty w pobliżu Neapolu w $1981 \mathrm{r}$. Zob. informacje zawarte na stronie internetowej https://pl.wikipedia.org/wiki/Scypionyks (dostęp 15.11.2016).

64 Pogląd taki wyraził B.W. Lewicki, cyt. za: W. Strykowski, Struktura filmu..., s. 15. 
problemu powoduje potrzebę rozważenia, czy audiowizualny utwór naukowy nie jest utworem zależnym, skoro ekipa filmowa „filmuje” utwór naukowy.

$\mathrm{Na}$ tak postawione pytanie należy udzielić negatywnej odpowiedzi. Twórca utworu zależnego ingeruje w sposób twórczy w cudzy utwór, wskutek czego powstaje nowe dzieło. Jest ono przejawem twórczej działalności autora utworu zależnego. Jednocześnie zakłada on, że w dziele zależnym będzie rozpoznawalne dzieło macierzyste ${ }^{65}$. W moim odczuciu założenie to powoduje, że naukowy utwór audiowizualny nie jest utworem zależnym. Wynika to stąd, że twórcy filmu nie dążą do tego, aby w dziele filmowym było rozpoznawalne dzieło naukowe - oni jedynie przedstawiają tezy naukowe i dowody na ich potwierdzenie, posługując się światłem i dźwiękiem jako tworzywem.

\section{Reżim prawny utworu audiowizualnego o charakterze naukowym}

Wydaje się, że próbując określić reżim prawny audiowizualnego utworu naukowego, należy uwzględnić następujące okoliczności. Po pierwsze, istotę wskazanej kategorii utworów, którą można sprowadzić do stwierdzenia, iż są to utwory, których twórcy przedstawiają fakty i teorie naukowe, korzystając ze światła i z dźwięku jako tworzywa. Po drugie, fakt, iż proces produkcji wymaga znacznego zaangażowania organizacyjnego i finansowego. Wydaje się, że okoliczności te wskazują, że do omawianej kategorii utworów należy stosować przepisy szczególne regulujące utwory audiowizualne (art. 69-73 pr. aut.).

Stworzenia audiowizualnego utworu naukowego podejmuje się jego producent $\mathrm{z}$ własnej inicjatywy albo z inicjatywy podmiotu, który z jakichś względów jest zainteresowany powstaniem filmu. W praktyce możliwa jest także koprodukcja w celu stworzenia określonego filmu. Producent audiowizualny ${ }^{66}$ zawiera z przedstawicielami ekipy filmowej (twórcami, a niekiedy także artystami wykonawcami) umowę o produkcję audiowizualną. W tej kwestii produkcja omawianej kategorii dzieł nie różni się od produkcji innych kategorii utworów audiowizualnych. Różnica pojawia się, kiedy uwzględnimy fakt, iż stroną umowy są także przedstawicie środowiska naukowego. Pełnią oni różne role przy produkcji filmu. Mogą wypowiadać się na ekranie albo pełnić rolę tzw. konsultantów naukowych. Ostatnia rola jest podobna do funkcji recenzenta w przypadku „klasycznego”

65 J. Barta, R. Markiewicz, w: System prawa prywatnego, t. 13, s. 53-54.

66 Pojęcie to zostało omówione w: P. Ślęzak, Umowy w zakresie współczesnych sztuk wizualnych, s. 316-319. 
dzieła naukowego i polega na ocenie poziomu merytorycznego audiowizualnego utworu naukowego.

Utwór, który powstanie, będzie efektem połączenia wysiłków twórczych naukowca/naukowców oraz osób wchodzących w skład ekipy filmowej. Osoby te zawierają porozumienie dotyczące połączenia wysiłków twórczych ${ }^{67}$. W konsekwencji należy uznać, że mamy w tym przypadku do czynienia $\mathrm{z}$ utworem współautorskim.

Producent audiowizualny będzie niekiedy zmuszony do nabycia prawa do „sfilmowania” utworu naukowego. Będzie to konieczne zwłaszcza wtedy, kiedy utwór audiowizualny ukaże fakty naukowe i teorie przedstawione w konkretnym dziele/dziełach naukowych. $Z$ uwagi na fakt, iż literatura naukowa wydawana jest na podstawie umów, na podstawie których autor - naukowiec - przenosi na wydawnictwo część majątkowych praw autorskich do dzieła naukowego, podmiotem, od którego producent audiowizualny może nabyć prawo do sfilmowania, jest najczęściej wydawnictwo.

W kontekście produkcji audiowizualnych utworów naukowych należy jeszcze rozważyć, czy znajduje zastosowanie przepis art. 14 pr. aut. Jest to przepis, zgodnie z którym instytucji naukowej przysługuje pierwszeństwo opublikowania utworu naukowego pracownika, o ile w umowie o pracę nie postanowiono inaczej. Przy założeniu, że audiowizualny utwór naukowy zostanie wydany na płytach, czyli powstaną egzemplarze udostępnione publiczności, pozornie pojawia się kolizja przepisów. Jeżeli przyjmiemy, że o charakterze audiowizualnego dzieła naukowego przesądza użycie obrazu i dźwięku jako tworzywa dla wyrażenia treści naukowych, to fakt ten powoduje, że nie można mówić w tej sytuacji o kolizji przepisów. Zastosowanie powinny znaleźć przepisy szczególne dotyczące utworów audiowizualnych. Cecha ta przesądza także o atrakcyjności przekazywanych treści dla potencjalnego odbiorcy. Przykładowo dla przeciętnego odbiorcy przekazem atrakcyjnym nie będzie opis prac wykopaliskowych w określonym obiekcie historycznym, ale film zawierający komputerową rekonstrukcję tego obiektu może być atrakcyjny. W doktrynie można tez spotkać stanowisko odmienne. Zadaniem A. Szewca, który przyjmuje istnienie w omawianej sytuacji utworu hybrydowego, ,jeżeli [...] określona treść może być wyrażona w różny sposób, np. słownie, graficznie albo techniką fotograficzną lub filmową, to przynajmniej w odniesieniu do utworów naukowych o charakterze dzieła powinna

67 Kwestię porozumienia jako przesłankę powstania współtwórczości omawia J. Banasiuk, Wspóttwórczość i jej skutki w prawie autorskim, Warszawa 2012, s. 120-142. 
decydować jego treść, a nie sposób jej wyrażenia"68 i w konsekwencji w przypadku zasygnalizowanej kolizji przepisami właściwymi dla filmu naukowego będą przepisy odnoszące się do utworów naukowych, a nie przepisy właściwe dla utworów audiowizualnych ${ }^{69}$.

\section{Podsumowanie}

Nie ulega wątpliwości, że treści naukowe mogą zostać przedstawione w postaci zapisu audiowizualnego. Powstaje wówczas utwór, który łączy przymioty utworu naukowego i audiowizualnego. Wydaje się jednak, że fakt ten nie uprawnia do wniosku, iż jest to utwór hybrydowy. W niniejszym tekście starałem się wykazać, że utwór ten jest zbliżony do utworu audiowizualnego w czystej postaci (zwłaszcza dokumentalnego), a nie do tradycyjnego utworu naukowego wyrażonego słowem, symbolami matematycznymi czy znakami graficznymi. W konsekwencji znajdują do niego zastosowanie odrębne przepisy dotyczące utworów audiowizualnych.

\section{Literatura}

Banasiuk J., Wspóttwórczość i jej skutki w prawie autorskim, Warszawa 2012.

Cherpillod I., L'objetdudroitd auteur, Lausanne 1985.

Czajka M., Ochrona praw twórców i producentów, Warszawa 2010.

Dessemontet F., Le droitd 'auteur, Lausanne 1999.

Flisak D., Utwór multimedialny w prawie autorskim, Warszawa 2008.

Galloux J.-Ch., Oeuvre audiovisuelle, w: JurisClasseur, Propriété littéraire et artistique, z. 1140, Paris 2002.

Haberstumpf H., Zur Individualität wissenschaftlicher Sprachwerke, Freiburg 1982.

Heller M., Filozofia nauki, Kraków 2016.

Hendrykowski M., Stownik terminów filmowych, Poznań 1994.

Inny stownik języka polskiego. A...Ó, red. M. Bańko, Warszawa 2000.

Kopff A., Dzieło sztuk plastycznych i jego twórca w świetle przepisów prawa autorskiego, „Zeszyty Naukowe Uniwersytetu Jagiellońskiego” 1961, z. 83.

Markiewicz R., Ochrona prac naukowych, „Zeszyty Naukowe Uniwersytetu Jagiellońskiego. Prace z Wynalazczości i Ochrony Własności Intelektualnej” 1990, z. 55.

\footnotetext{
68 A. Szewc, Dzieła naukowe..., s. 27.

${ }^{69}$ Ibidem.
} 
Ożóg M., Podstawowe pojęcia ustawy z 30.06.2005 r. o kinematografii, ,Zeszyty Naukowe Uniwersytetu Jagiellońskiego. Prace z Prawa Własności Intelektualnej” 2009, z. 104.

Paschke M., Medienrecht, Heidelberg-London-New York 2009.

Prawo autorskie i prawa pokrewne. Komentarz, red. J. Barta, R, Markiewicz. Warszawa 2011.

Sokołowska D., Pojęcie i postacie utworu naukowego $w$ świetle prawa autorskiego, „Ruch Prawniczy Ekonomiczny i Socjologiczny” 2015, z. 2.

Strykowski W., Struktura filmu naukowo-dydaktycznego, Poznań 1973.

Strykowski W., Wstęp do teorii filmu dydaktycznego, Poznań 1977.

System prawa prywatnego, t. 13: Prawo autorskie, red. J. Barta, Warszawa 2013.

Szewc A., Dzieła naukowe i ich status w prawie autorskim, „Państwo i Prawo” 1997, nr 10.

Ślęzak P., Dzieło multimedialne w świetle polskiego prawa autorskiego, „Zeszyty Naukowe Uniwersytetu Jagiellońskiego. Prace z Wynalazczości i Ochrony Własności Intelektualnej” 2003, z. 83.

Ślęzak P., Prawo autorskie. Podręcznik dla studentów szkół filmowych, Katowice 2015.

Ślęzak P., Umowy w zakresie współczesnych sztuk wizualnych, Warszawa 2012.

Wierski D., Rodzaje i gatunki filmowe, s. 1, https://pl.wikipedia.org/wiki/Film_edukacyjny (dostęp 3.11.2016).

Wojciechowska A., Autorskie prawa osobiste twórców dzieła audiowizualnego, „Zeszyty Naukowe Uniwersytetu Jagiellońskiego. Prace z Wynalazczości i Ochrony Własności Intelektualnej” 1999, z. 72.

\section{Źródla internetowe}

https://pl.wikipedia.org/wiki/Nauka

https://pl.wikipedia.org/wiki/Metodologia_nauk

http://www.edukacjafilmowa.pl/materialy-edukacyjne/inne-opracowania/item/2142rodzaje-i-gatunki-filmowe

https://pl.wikipedia.org/wiki/Animacja_komputerowa

http://kopalniawiedzy.pl/dinozaury-stalocieplnosc-zmiennocieplnosc-energetykametabolizm, 8989

https://pl.wikipedia.org/wiki/Zwierz\%C4\%99_sta\%C5\%82ocieplnehttp://www.geekweek.pl/aktualnosci/23257/dinozaury-byly-stalocieplne

https://pl.wikipedia.org/wiki/Scypionyks 


\title{
SCIENTIFIC AUDIOVISUAL WORK HYBRID WORK AS?
}

\begin{abstract}
Summary
This text is a trial of answering to the question if the scientific audiovisual work is a hybrid work. It would be a work which combines the features of both, scientific and audiovisual work. The Author gives to the question made a negative answer. The works evaluated constitute one of audiovisual work's subcategory. For accepting this concept speaks the fact that the discussed type of work contains the "layer", which provides the scientific contents, but updated by extremely important "layer" which constitutes the expression of audiovisual author's invention. The audiovisual layer allows to make scientific subjects accessible and attractive for the readers, who are not specialist in the area in question. According to Author's "scientific audiovisual work" is a concept collective, which includes three subcategories at least: documentary, educational film and animated film. Alongside this category there are "pure" scientific works the element of which is an audiovisual registration.
\end{abstract}

Keywords: scientific audiovisual work, hybrid work 